\title{
Injerto escalonado de calota para manejo de enoftalmos y distopia postraumática
}

\author{
Tiered skull graft for the management of post-traumatic enophthalmos \\ and dystopia
}

\author{
O.A. Vega Lagos', J.E. Abril Rodríguez², L.F. Peñuela Balaguera, V.G. Páramo Jiménez
}

\begin{abstract}
Resumen: Casi un $90 \%{ }^{1}$ de los traumatismos del macizo craneofacial involucran las órbitas, y un alto porcentaje de los mismos generan secuelas como son el enoftalmos y la distopia postraumáticos.

Existen en la literatura numerosas referencias de técnicas quirúrgicas para corrección de dichas secuelas y diversos materiales para la reconstrucción orbitaria posterior al trauma, pero pocas de ellas se han encaminado a devolver la anatomía original al suelo orbitario, por tal razón se considera perentorio desarrollar una técnica sencilla y eficaz para la corrección de los defectos antes descritos. El presente artículo refiere la utilización de una nueva técnica quirúrgica para el manejo de las secuelas ya mencionadas usando un injerto escalonado de calota en el suelo de la órbita, dado que este último es una excelente opción para la colocación de injertos, debido a su baja tasa de reabsorción y mínimas reacciones adversas.

Pacientes. Cuatro pacientes (1 mujer, 3 hombres) con un promedio de edad de 23 años (rango entre 17 y 27 años) con antecedente de trauma facial y compromiso de la órbita, que fueron tratados entre 2004 y 2007, en el Hospital Central de la Policía Nacional y Hospital El Tunal (Bogotá, Colombia), previa autorización mediante firma de consentimiento informado. En ellos se utilizó la técnica de injerto escalonado de calota para corrección de enoftalmos y distopia postraumática. Se describen resultados con un tiempo de seguimiento entre 11 y 42 semanas.

Resultados. En todos los pacientes se observó disminución del continente orbitario y proyección simétrica del globo ocular en sentido antero-posterior y vertical, así como también mejoría completa de la diplopía, luego de la colocación del injerto escalonado de calota en el suelo orbitario.

Conclusión. Se trata de una técnica sencilla, de bajo costo, mínima morbilidad, con resultados predecibles y satisfactorios a corto y medio plazo.
\end{abstract}

Palabras clave: Blow out; Enoftalmos; Diplopía; Distopia; calota.

Recibido: 20.6.07

Aceptado: 27.111 .08
Abstract: Almost $90 \%{ }^{1}$ of traumatic injuries to the craniofacial massif involve the eye sockets, and a large proportion of these injuries generate sequelae, such as post-traumatic enophthalmos and dystopia.

The literature contains numerous references to surgical techniques for the correction of these sequelae and diverse materials for orbital reconstruction after trauma. However, few of them have been designed to restore the original anatomy of the orbital floor. For that reason, it is important to develop a simple and effective technique for correcting orbital damage. The present article describes the use of a new surgical technique for the management of the sequelae mentioned using a tiered skull graft on the floor of the orbit. It is an excellent option for graft placement because of its low resorption rate and minimal adverse reactions.

Patients. Four patients ( 1 woman, 3 men), average age 23 years (range 17-27 years) and history of facial trauma with orbital involvement were treated between 2004 and 2007 at the Hospital Central de la Policía Nacional and Hospital El Tunal (Bogotá, Colombia). All of them authorized the procedure by signing an informed consent form. The tiered graft technique was used for the post-traumatic correction of enophthalmos and dystopia. Results with a follow-up time of 11 to 42 weeks are reported.

Results. All the patients exhibited a reduction in the eye socket and symmetrical projection of the eyeball in anteroposterior and vertical direction, as well as complete improvement of the diplopia after the tiered skull graft was used to repair the orbital floor.

Conclusion. The technique is simple and inexpensive, with minimal morbidity and predictable and satisfactory results in the short and intermediate term.

Key words: Blow out; Enophthalmos; Diplopia; Dystopia; Cranium.
1 Cirujano Oral y Maxilofacial

2 Residente IV año Cirugía Oral y Maxilofacial

3 Residente III año Cirugía Oral y Maxilofacial

4 Residente II año Cirugía Oral y Maxilofacial

Hospital Central de la Policía Nacional.

Servicio de Cirugía Oral y Maxilofacial. Bogotá, D.C. Colombia.

\section{Correspondencia:}

Dr. Omar Alejandro Vega

Apartado aéreo 52309

Bogotá, D.C. Colombia

E-mail: omalvega@yahoo.com 


\section{Introduccion}

Según datos epidemiológicos las órbitas se comprometen en el $89 \%$ de los traumatismos craneofaciales y en el $71 \%$ de los traumatismos orbitarios el globo ocular no sufre lesión ni alteración funcional alguna. En la vida civil, el $80 \%$ de las lesiones traumáticas son originadas por accidentes de tráfico (motos y autos) y el $20 \%$ restante por asaltos, armas de fuego y accidentes en el hogar. ${ }^{1}$ Cuando se produce trauma orbitario los sitios que se comprometen con mayor frecuencia son en orden decreciente: Suelo orbitario 58\%, Pared Lateral 32\%, Pared Medial 24\%, Reborde Orbitario 11\% y Techo 3\%.2 Pearl en 1992 afirma que el 50\% de los pacientes con fracturas blow-out presentan fracturas de pared medial asociadas. ${ }^{3}$ Converse y Smith en 1959 hacen referencia a que cuando se presentan fracturas malares y de suelo de órbita conminutas las complicaciones más frecuentes son el enoftalmos y la diplopia. ${ }^{4}$

A lo largo de la historia se han descrito diferentes clasificaciones de las fracturas orbitarias pero es Lang en 1889 quien la refiere como entidad clínica, específicamente como fractura blow-out. ${ }^{5}$ No obstante su definición más profunda fue dada por Converse y Smith en 1959.4 Por su parte autores como Rene LeFort en 1901 y Pfeiffer en 1943 son quienes describen la fisiopatología de este tipo de fracturas. ${ }^{6}$

La literatura científica reciente se ha enfocado en describir el mejor abordaje quirúrgico y el mejor material para la reconstrucción del tejido perdido, sin embargo pocos autores han encaminado sus estudios a devolver la morfología perdida tras el trauma al suelo de la órbita. . $^{-9}$

Dado que el suelo de la órbita es una estructura ósea con una morfología compleja que presenta una longitud desde el reborde orbitario libre hasta el apex de entre 40 a $45 \mathrm{~mm}$ en la cual la porción anterior al ecuador del globo es cóncava y la porción posterior es convexa, ${ }^{10}$ no es difícil sospechar que el material que se coloque para su reconstrucción, además de ser biocompatible y con un costo favorable para el paciente y/o los servicios de salud, debe devolver la anatomía original perdida.

Hay que tener en cuenta igualmente que el diámetro del globo ocular es de aproximadamente $25 \mathrm{~mm}$ y que la distancia de la porción corneana respecto al reborde orbitario es de 3 a $5 \mathrm{~mm},{ }^{11}$ por tal razón y considerando la longitud del suelo, el ecuador del globo ocular debe encontrarse entre 10 a $11 \mathrm{~mm}$ del reborde libre inferior en su porción central.

Asumiendo la configuración antes descrita, se diseñó un injerto escalonado de calota, el cual se utilizó en cuatro pacientes para el tratamiento tardío de secuelas de enoftalmos y distopia postraumática.

\section{Técnica quirúrgica}

Se desarrollo esta técnica en cuatro pacientes, en quienes se realizó abordaje en cuero cabelludo en zona parietal contralateral al hemisferio cerebral dominante y se tomó injerto de calota de tabla externa, este se obtuvo de manera sencilla y práctica a través de incisión lineal de aproximadamente $5 \mathrm{~cm}$ en el cuero cabelludo y

\section{Introduction}

According to epidemiologic data, the orbit is involved in $89 \%$ of craniofacial injuries. In $71 \%$ of orbital injuries, the eyeball does not experience any injury or functional alteration. In civil life, $80 \%$ of traumatic injuries are originated by traffic accidents (motorcycles and cars) and the remaining $20 \%$ by assault, firearms, and home accidents. ${ }^{1}$ When orbital trauma occurs, the sites most frequently affected, in decreasing order, are: orbital floor, 58\%; lateral wall, 32\%; medial wall, 24\%; orbital rim, 11\%; and roof, 3\%. ${ }^{2}$ Pearl in 1992 affirmed that $50 \%$ of patients with blow-out fractures present associated medial wall fractures. ${ }^{3}$ Converse and Smith, in 1959, reported that when comminuted malar and orbital floor fractures occur, the most frequent complications are enophthalmos and diplopia. ${ }^{4}$

Throughout history, different classifications of orbital fractures have been made, but it was Lang, in 1889, who specifically referred to blow-out fractures as a clinical entity. ${ }^{5}$ Nonetheless, the deepest definition was given by Converse and Smith in 1959. ${ }^{4}$ On their part, authors like Rene LeFort, in 1901, and Pfeiffer, in 1943, described the pathophysiology of this type of fractures. 6

Recent scientific literature has focused on describing the best surgical approach and the best material for the reconstruction of the lost tissue. However, few authors have conceived their studies to return the morphology of the orbital floor that was lost after the trauma. . $^{-9}$

As the orbital floor is a bone structure with a complex morphology that has a length from the free orbital rim to the apex of 40 to $45 \mathrm{~mm}$, in which the part anterior to the equator of the eyeball is concave and the part posterior to the equator is convex, 10 it is not difficult to suspect that the material that is used for its reconstruction not only should be biocompatible but have a cost favorable to the patient and/or health services, and restore the original anatomy.

The fact that the diameter of the eyeball is approximately $25 \mathrm{~mm}$ and that the distance of the corneal portion from the orbital rim is 3 to $5 \mathrm{~mm}$ should be taken into account." For that reason and considering the length of the orbital floor, the equator of the eyeball should be 10 to $11 \mathrm{~mm}$ from the lower free rim in its central part.

Assuming the configuration described above, a tiered skull graft was designed, which was used in four patients for the delayed treatment of post-traumatic sequelae of enophthalmos and dystopia.

\section{Surgical technique}

This technique was developed in four patients, in which the approach was performed in the scalp, in the parietal zone contralateral to the dominant cerebral hemisphere. The graft was obtained from the external table of the skull. It was obtained in a simple and practical way through a $5-\mathrm{cm}$ 
disección por planos hasta el hueso haciendo hemostasia; posteriormente se confeccionó el injerto con fresa quirúrgica de fisura $\mathrm{N}^{\circ} 703$, con una base de $35 \mathrm{~mm}$ de longitud en sentido anteroposterior y longitud media lateral según cada caso. Se retira el injerto con cinceles respetando a toda costa la cortical interna y se coloca sobre el fragmento mayor un segmento menor que corresponda a la zona retroecuatorial del globo ocular, éste tenía una longitud anteroposterior de $15 \mathrm{~mm}$ y altura total de $4 \mathrm{~mm}$ aproximadamente; dicha fijación fue realizada con dos tornillos del sistema 1,5 con una longitud de 5 a $7 \mathrm{~mm}$ (Fig. 1). El objeto de elaborar el injerto en este sentido es buscar elevar y proyectar el globo ocular. Adicionalmente se utiliza el protocolo de adición de plasma rico en plaquetas PRP.

Luego de la confección del injerto, éste fué fijado al reborde infraorbitario mediante placas del sistema 1,5.

\section{Casos clínicos}

\section{Caso 1}

Mujer de 17 años que sufre accidente de tránsito el 25 de Septiembre del 2004 con fractura panfacial. Se realiza reducción abierta y fijación interna de las fracturas 1 mes posterior al trauma debido a la condición neurológica de la paciente. Secuelas posquirúrgicas: enoftalmos, distopia y epífora izquierda (Fig. 2). A los 20 meses de la intervención se realiza corrección del enoftalmos y distopia postraumática de manera simultánea, mediante injerto escalonado de calota en suelo de la órbita (Figs. 3-6). Tanto en la evaluación postoperatoria inmediata como a las 42 semanas postoperatorias se evidencia la corrección del enoftalmos y la distopia (Fig. 7).

\section{Caso 2}

Hombre de 23 años de edad que presenta enoftalmos, diplopia y distopia derechas posteriores a accidente de tránsito con fractura blow-out derecha (Fig. 8). Se realiza la corrección de dichas secuelas realizando injerto escalonado de calota en piso de orbita derecho y adición de gel de plasma rico en plaquetas, 11 meses posterior al accidente, mediante abordaje infraorbitario a través de cicatriz previa (Fig. 9). Tanto

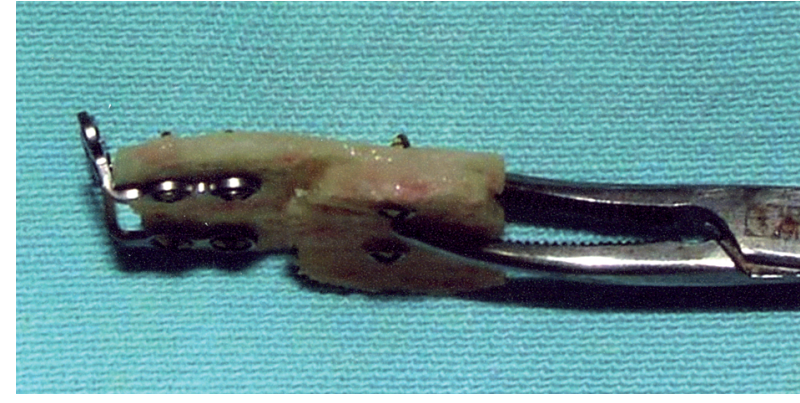

Figura 1. Injerto escalonado de calota. Figure 1. Tiered skull graft.
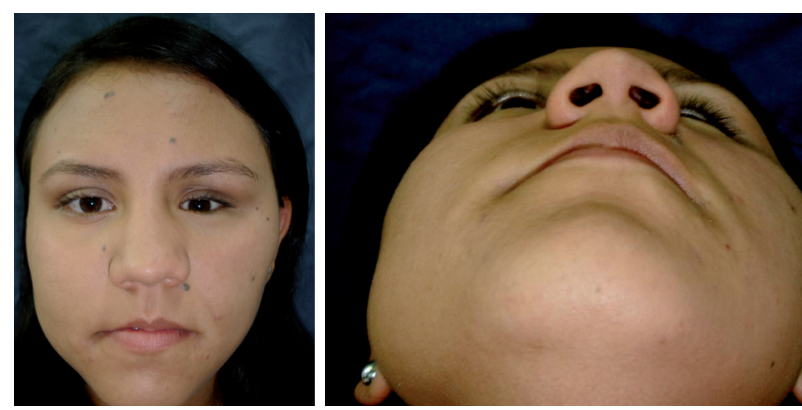

Figura 2. Vista frontal y submentovertex. Se observa compromiso estético importante, asimetría facial, enoftalmos derecho y depresión de tercio medio ipsilateral.

Figure 2. Frontal and submentonian view. Impaired aesthetic appearance, face asymmetry, right enophthalmos, and same-side depression of the middle third are evident.

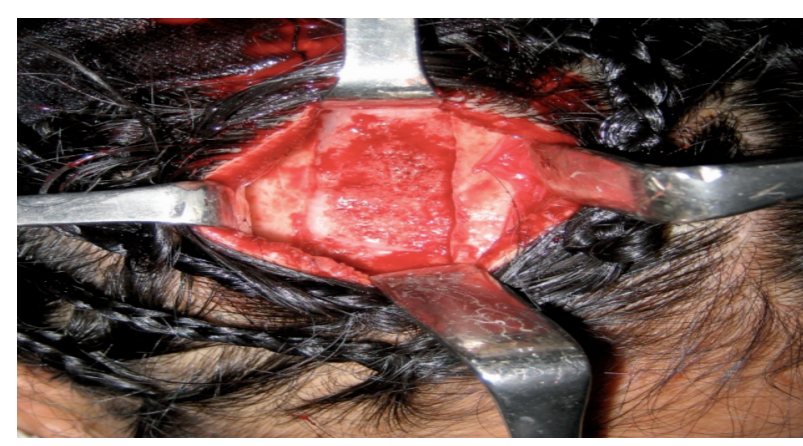

Figura 3. Toma de injerto de calota.

Figure 3. Preparation of the skull graft.
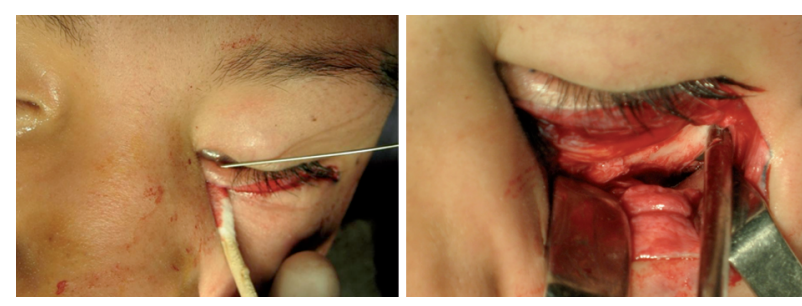

Figura 4. Abordaje subciliar para exponer reborde infraorbiatrio. Figure 4. Subciliary approach to expose the infraorbital rim. linear incision in the scalp and dissection by planes to the bone, controlling bleeding. The graft was prepared with a tapered surgical burr 703 with a base $35 \mathrm{~mm}$ long in anteroposterior direction and a mean lateral length according to each case. The graft was raised with chisels, carefully conserving the internal cortex, and a smaller segment was placed on the larger fragment, which corresponds to the retroequatorial zone of the eyeball. It had an anteroposterior length of approximately 15 $\mathrm{mm}$ and a total height of $4 \mathrm{~mm}$. Fixation was performed with two screws of the 1.5 system with a length of 5 to $7 \mathrm{~mm}$ (Fig. 1). The object of preparing the graft this way is to elevate and project the eyeball. In addition, the protocol of addition of plateletrich plasma (PRP) was applied.

After the preparation of the graft, it was fixed to the infraorbital rim by means of system 1.5 plates.

\section{Clinical cases}

\section{Case 1}

A 17-year-old woman who suffered a traffic accident on 25 September 2004 with a panfacial fracture. Open reduction and internal fixation of the fractures was performed 1 month after trauma due to the neurological condition of the patient. Postoperative sequelae: left enophthalmos, dystopia, and epiphora (Fig. 2). At 20 months of the intervention, the post-traumatic enophthalmos and dystopia were corrected simultaneously using a tiered skull graft on the floor of the orbit (Figs. 3, 4, 5 and 6). In both the imme- 
en el postoperatorio, como a las 16 semanas, se observan ejes pupilares más simétricos y mejoría importante de la proyección del globo ocular derecho y especialmente de la diplopia postraumática.

\section{Caso 3}

Hombre de 27 años con secuelas de trauma contundente en hemicara izquierda, con fractura blow-out no tratada. Como consecuencia presentó enoftalmos, distopia y diplopia izquierdas (Fig. 11); 18 meses posterior al trauma se realiza la corrección de dichas secuelas mediante la colocación de injerto escalonado de calota en suelo de órbita, previo abordaje transconjuntival izquierdo (Fig. 12). Observándose en la evaluación postoperatoria mejoría estética y funcional importante de las condiciones ya descritas (Fig. 13).

\section{Caso 4}

Hombre de 27 años que sufrió trauma facial y craneoencefálico producido por accidente de transito en una motocicleta. Es remitido por el servicio de Oftalmología del Hospital Central de La Policía para valoración y tratamiento de enoftalmos derecho, al examen físico también se evidenció paresia incompleta de III par craneal derecho y diplopia
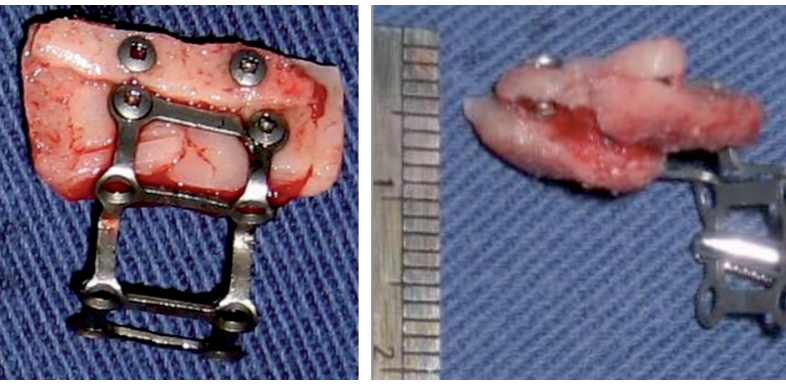

Figura 5. Confección de injerto de calota escalonado fijado mediante tornillos y placa del sistema 1.5.

Figure 5. Preparation of the tiered skull graft using screws and a system 1.5 plate.

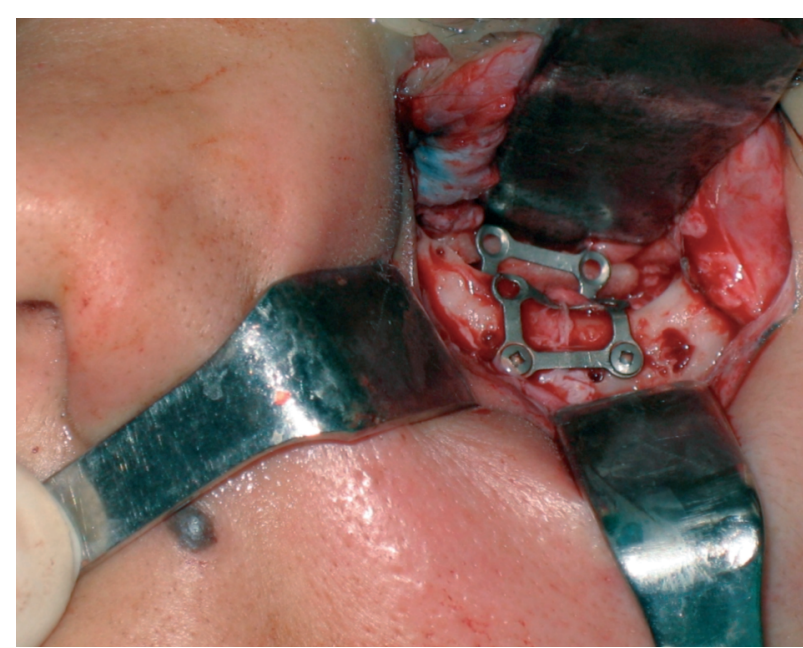

Figura 6. Colocación del injerto en suelo de órbita. Figure 6. Positioning the graft on the orbital floor. diate postoperative evaluation and at 42 postoperative weeks, correction of the enophthalmos and dystopia was demonstrated (Fig. 7).

\section{Case 2}

A 23-year-old man who presented right enophthalmos, diplopia, and dystopia and a right blow-out fracture after a traffic accident. (Fig. 8). These sequelae were corrected by applying a tiered skull graft to the floor of the right orbit, 11 months after the accident via an infraorbital approach through a previous scar. Platelet-rich plasma gel was added (Fig. 9). In the postoperative period and at 16 weeks, more symmetrical pupil axes and an important improvement in the projection of the right eyeball were observed, especially in the post-traumatic diplopia.

\section{Case 3}

A 27-year-old man with sequelae of blunt trauma to importante referida (Fig. 14). A los 14 meses del accidente se realiza la corrección de enoftalmos postraumático mediante injerto escalonado de calota en suelo de orbita derecha y adición de gel de plasma rico en plaquetas. En el postoperatorio inmediato se evidenció mejor proyección antero-posterior del globo ocular y el the left side of the face and untreated blow-out fracture. As a consequence, the patient presented left enophthalmos, dystopia, and diplopia (Fig. 11). Eighteen months after the injury, these sequelae were corrected by applying a tiered skull graft to the orbital floor through a left transconjuncti-
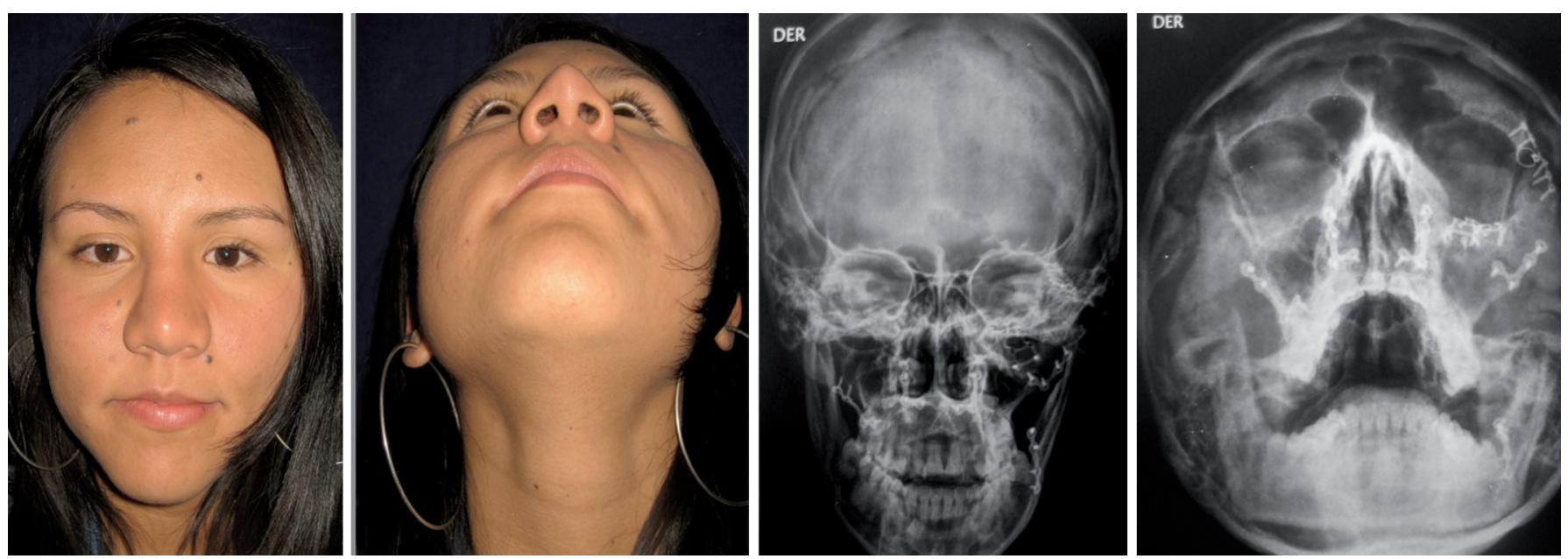

Figura 7. POP 42 Semanas. Corrección de enoftalmos y distopia.

Figure 7. 42 weeks after surgery. Correction of enophthalmos and dystopia. 
paciente refirió mejoría importante de la diplopia. También fue evidente la mejoría lograda en cuanto a proyección anterosuperior del globo ocular derecho. Estos resultados se han mantenido estables a las 16 semanas de control postoperatorio (Fig. 15).

\section{Resultados}

Se operaron un total de cuatro pacientes con un promedio de edad de 23 años (rango entre 17 y 27 años) con antecedente de trauma facial y compromiso de la órbita, que fueron tratados entre 2004 y 2007, en el Hospital Central de la Policia Nacional y Hospital El Tunal (Bogotá, Colombia); en ellos se utilizó la técnica de injerto escalonado de calota para corrección de enoftalmos y distopia postraumática (Tabla 1).

En todos los pacientes se observó disminución del continente orbitario y proyección simétrica del globo ocular en sentido ántero-posterior y vertical, así como también mejoría completa de la diplopía, luego de la colocación del injerto escalonado de calota en el suelo orbitario.

\section{Discusión}

El trauma facial es una constante en la casuística del cirujano oral y maxilofacial en nuestro medio y por esto se hace necesario conocer el manejo adecuado de las fracturas que comprometen el macizo cráneofacial y de esta manera prevenir en el paciente secuelas postquirúrgicas. Una de las entidades que se presentan con mayor frecuencia como consecuencia de fracturas faciales es el enoftalmos y la causa principal es la inadecuada reducción de fracturas malares, lo cual causa un desequilibrio entre el volumen y el contenido orbitario produciendo desplazamiento posterior y en ocasiones inferior del globo ocular. ${ }^{8}$

Para el manejo adecuado de las fracturas de la órbita es necesario conocer la fisiopatología de dichas fracturas y la transmisión de fuerzas a través de las paredes orbitarias o del propio globo ocular. Igualmente tener en cuenta que son la pared medial y el piso orbitario, los sitios de menor resistencia y los que en mayor proporción sufren fracturas. Grant menciona que cambios en el 10\% del volumen orbital generan variación en la posición del globo. ${ }^{3}$

Básicamente se observan dos tipos de fracturas blow-out: extensión posterior al eje del globo por fractura del suelo de la órbita o

\section{Results}

A total of four patients, average age 23 years (range 17 27 years), with a history of facial trauma that affected the orbit were treated between 2004 and 2007 at the Hospital Central de la Policía Nacional and Hospital El Tunal (Bogotá, Colombia). The tiered skull graft technique was used for post-traumatic correction of enophthalmos and dystopia (Table 1).

All the patients exhibited a reduction of the eye socket and symmetrical projection of the eyeball in anteroposterior and vertical direction, as well as complete improvement of the diplopia after a tiered skull graft of the orbital floor. 
fractura concomitante de la pared medial. 8

En la mayoría de técnicas utilizadas para la corrección de secuelas orbitales postraumáticas una de las principales desventajas es la no restauración de la anatomía orbitaria adecuada, por lo cual el globo ocular no recupera su posición original, resultando en enoftalmos y distopia. Teniendo en cuenta que el suelo orbitario presenta una concavidad en su porción anterior y una convexidad en la posterior lo cual mantiene al globo ocular en posición, presentamos la técnica de injerto escalonado de calota con el fin de regenerar la anatomía perdida y lograr que el globo ocular se proyecte hacia adelante y arriba. Esta técnica al ser un injerto autólogo presenta mínima tasa de reabsorción y la morbilidad del sitio donante no es significativa.

Existen en la literatura varias técnicas para la corrección de fracturas blow-out y sus secuelas correspondientes, encontrando técnicas de corrección endoscópica, corrección con materiales aloplásticos e injertos autólogos, entre otros. Los injertos autólogos presentan la mayor tasa de éxito debido a su menor patrón de reabsorción, menor posibilidad de rechazo y disminución de costos. Zins y Whitaker en 1983 aseguran que el injerto óseo de origen intramembranoso presenta menor porcentaje de reabsorción frente a los injertos óseos endocondrales. Zins en 1984 agrega que dicha condición se debe al fenómeno de revascularización temprana que presenta el injerto intramembranoso y a su microarquitectura. El hueso de origen intramembranoso presenta una corteza delgada y una capa más densa de hueso esponjoso que el hueso endocondral, y son éstas diferencias las bases para la resorción diferencial de los injertos. Ozaki y Buchman en 1998, notaron que los injertos corticales se reabsorben menos que los esponjosos y atribuyen esto más a la arquitectura ósea que al propio origen embriológico.

Respecto a la morbilidad del sitio donante, Krauss y Gatot,12 en el 2001 evalúan la eficacia de la reparación de defectos de suelo de órbita con cartílago nasoseptal, encontrando una alta tasa de éxito con mínima morbilidad del sitio donante. Castellani en el 2002 realiza reparación de defectos de lado derecho.

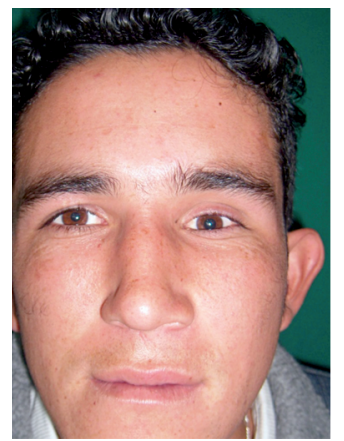
no con chips óseos. with bone chips.

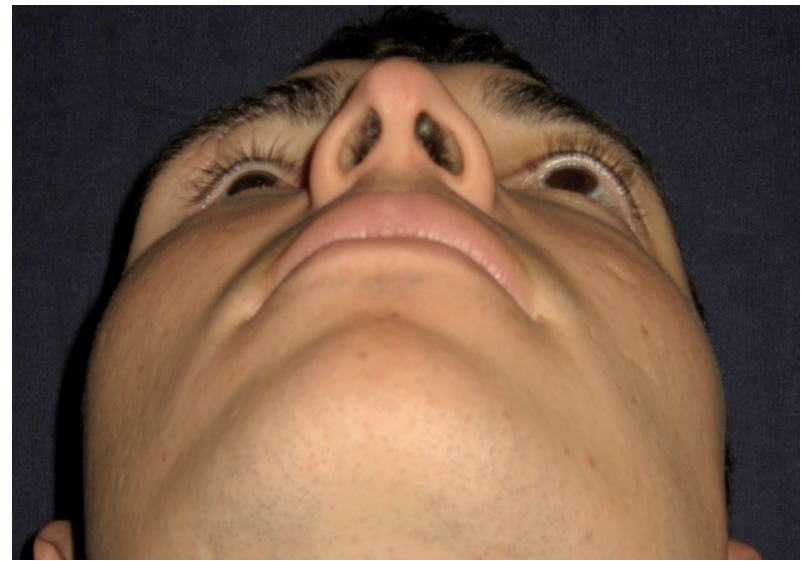

Figura 10. Postoperatorio 16 semanas con evidencia de corrección importante en el enoftalmos y diplopía postraumáticas en

Figure 10. Sixteen weeks after surgery, the correction of the posttraumatic right enophthalmos and diplopia is evident.

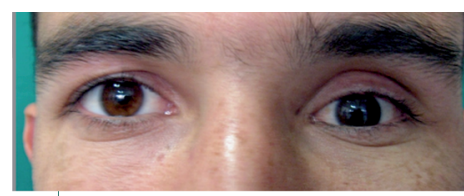

Figura 11. Vista frontal y submentovertex prequirúrgicas. Figure 11. Preoperative frontal and submentonian view.

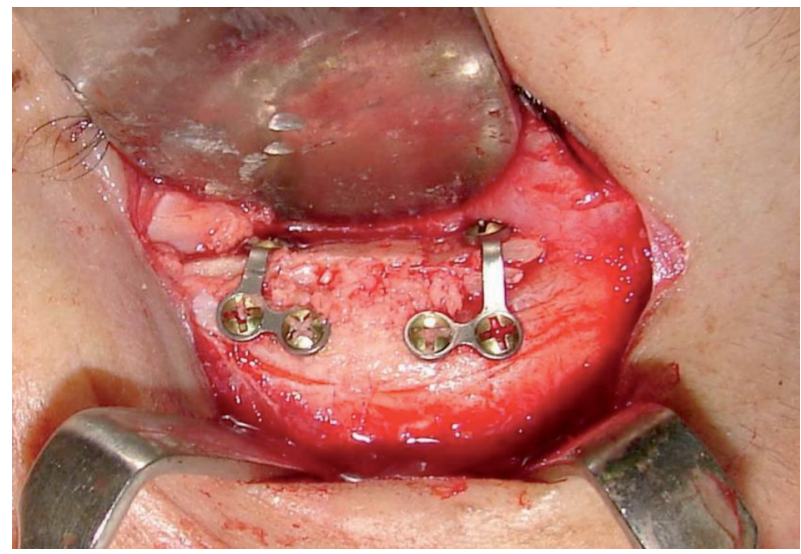

Figura 12. Fig 12. Colocación de injerto en piso de orbita y relle-

Figure 12. Placement of the bone graft on the orbital floor and filling

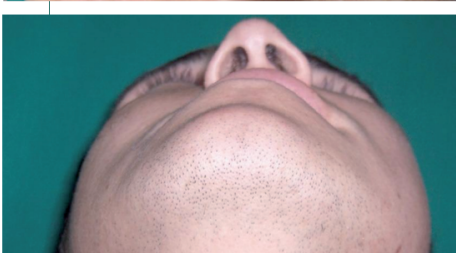
socket or the eyeball itself. It also should be remembered that the medial orbital wall and orbital floor are the points of least resistance and the areas most likely to fracture. Grant notes that changes of $10 \%$ in the orbital volume generate variations in eyeball position. ${ }^{3}$ Two basic types of blow-out fracture are observed: posterior extension to the eyeball axis due to fracture of the orbital floor and concomitant fracture of the medial wall. ${ }^{8}$

In most of the techniques used to correct post-traumatic orbital sequelae, one of the main disadvantages is that it does not restore proper orbital anatomy and the eyeball does not recover its original position, resulting in enophthalmos and dystopia. Considering that the orbital floor has an anterior concavity and posterior convexity that keep the eyeball positioned, we report 
suelo de la órbita con cartílago de concha auricular obteniendo un éxito de más del $90 \%$ con mínima morbilidad. ${ }^{13}$

Otro material utilizado son las mallas preformadas de titanio, con la ventaja de devolver la anatomía orbitaria en casi todos sus detalles. En el 2006 Schon y Metzger obtuvieron éxito del $100 \%$ en la reparación de defectos de piso de orbita, con ventajas adicionales como la facilidad de colocación, menor tiempo quirúrgico, mayor precisión y menos invasividad. Con el injerto escalonado de calota, obtenemos los mismos beneficios evitando la utilización de cuerpos extraños en relación directa con el globo ocular con los riesgos que esto representa.

Muñoz - Guerra y cols. en el 2000 enumeran las desventajas de los materiales autógenos y aloplásticos. Respecto a los materiales autógenos mencionan una tasa de reabsorción impredecible, movilidad del implante, morbilidad de la zona donante y gran dificultad para generar la anatomía orbitaria perdida. De los materiales aloplásticos mencionan infección, extrusión del implante, reacción tisular, y diplopia residual. ${ }^{15}$

\section{Conclusiones}

La técnica de reconstrucción del suelo orbitario presentada es sencilla, fácil de realizar y de resultados predeci-
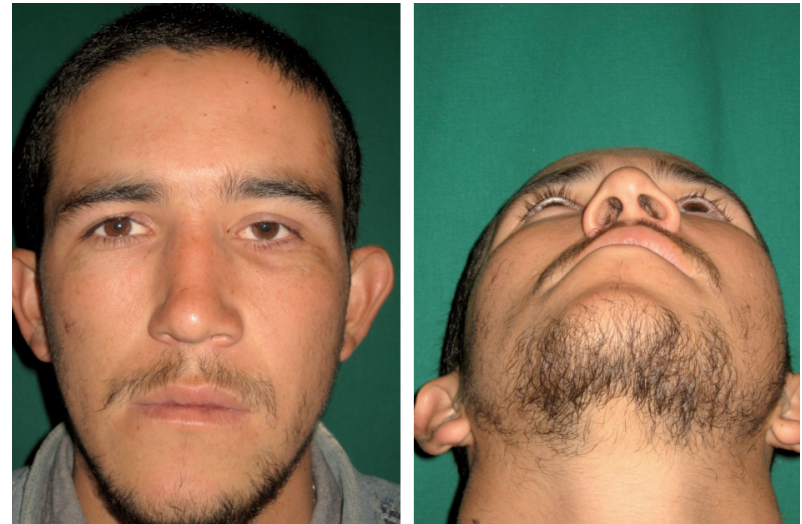

Figura 13. Fotografías postoperatorias a las 20 semanas. Figure 13. Postoperative photographs at 20 weeks.
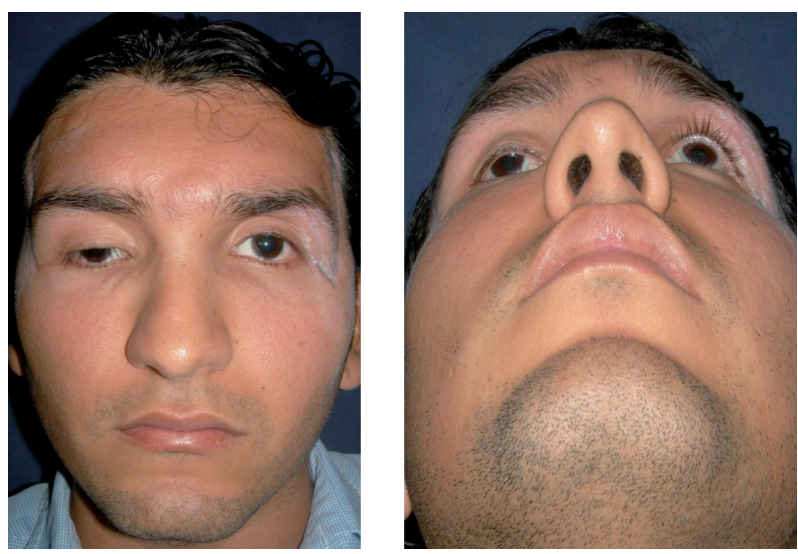

Figura 14. Vista frontal y submentovertex prequirúrgicas. Figure 14. Preoperative frontal and submentonian view the technique of tiered skull graft for regenerating the lost anatomy and restoring the forward and upward projection of the eyeball. As this is an autologous graft, the resorption rate is minimal and the morbidity of the donor site is not significant.

Several techniques are described in the literature for the correction of blow-out fractures and their sequelae, including endoscopic correction techniques and correction with alloplastic materials and autologous grafts, among others. Autologous grafts have the highest success rate due to less resorption, less possibility of rejection, and lower costs. Zins and Whitaker, in 1983, claim that bone grafts of intramembranous origin have a lower rate of resorption than endochondral bone grafts. Zins, in 1984, added that this condition is due to the early revascularization phenomena that the intramembranous graft presents and its microarchitecture. Bone of intramembranous origin has a thin cortical layers and a denser layer of cancellous bone than endo-
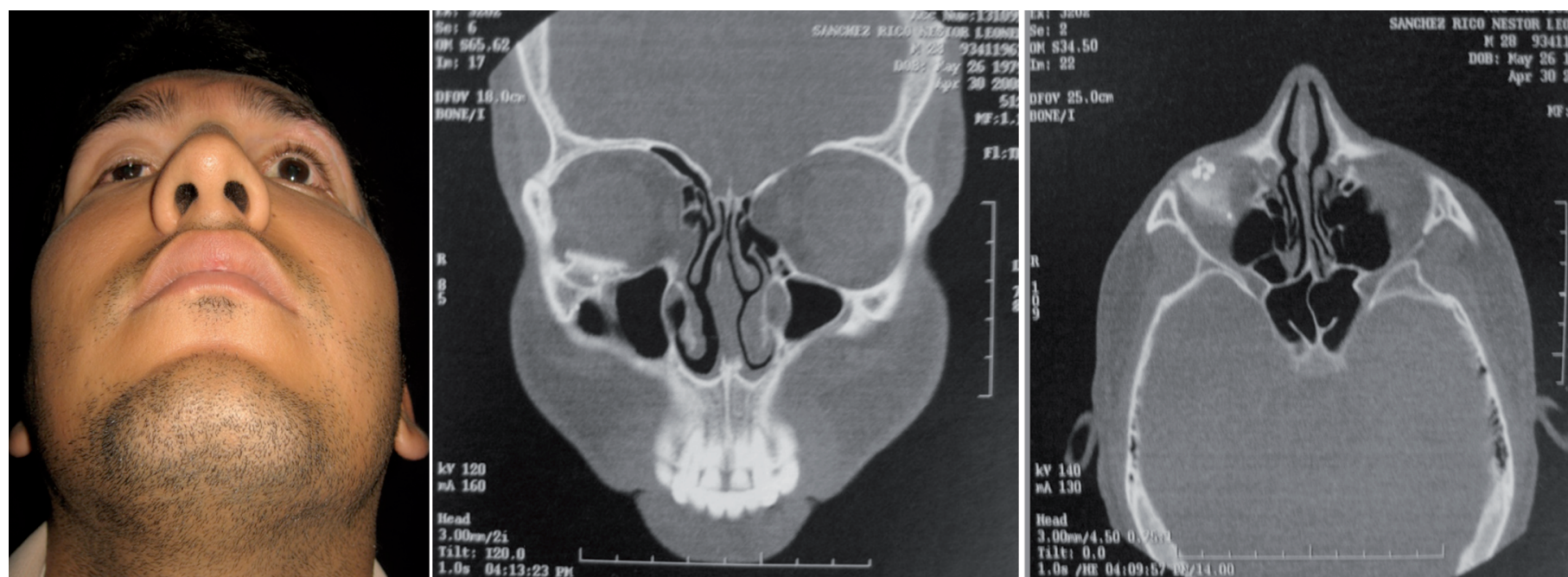

Figura 15. Apariencia clínica y tomográfica a las 16 semanas postoperatorias.

Figure 15. Clinical and tomographic appearance 16 weeks after surgery. 
Tabla 1. Resumen de datos clínicos

\begin{tabular}{|c|c|c|c|c|c|c|c|}
\hline Genero & $\begin{array}{l}\text { Edad } \\
\text { (Años) }\end{array}$ & Diagnóstico & $\begin{array}{l}\text { Tratamiento } \\
\text { inicial }\end{array}$ & Secuelas & $\begin{array}{l}2^{\circ} \text { Tiempo } \\
\text { quirúrgico }\end{array}$ & Seguimiento & PRP \\
\hline Femenino & 17 & Fractura Panfacial & $\begin{array}{l}\text { Reducción abierta, } \\
\text { fijación interna rígida }\end{array}$ & $\begin{array}{l}\text { Enoftalmos } \\
\text { Distopia } \\
\text { Epífora }\end{array}$ & $\begin{array}{l}20 \text { meses } \\
\text { Injerto escalonado } \\
\text { de calota }\end{array}$ & 42 Semanas & No \\
\hline Masculino & 23 & $\begin{array}{c}\text { Fractura Blow-out } \\
\text { derecha }\end{array}$ & $\begin{array}{l}\text { Reducción abierta, } \\
\text { fijación interna rígida }\end{array}$ & $\begin{array}{l}\text { Enoftalmos } \\
\text { Distopia } \\
\text { Diplopia }\end{array}$ & $\begin{array}{c}11 \text { meses } \\
\text { Injerto escalonado } \\
\text { de calota }\end{array}$ & 16 Semanas & Sí \\
\hline Masculino & 27 & $\begin{array}{c}\text { Fractura Blow-out } \\
\text { izquierda }\end{array}$ & Ninguno & $\begin{array}{l}\text { Enoftalmos } \\
\text { Distopia } \\
\text { Diplopia }\end{array}$ & $\begin{array}{c}18 \text { meses } \\
\text { Injerto escalonado } \\
\text { de calota }\end{array}$ & 20 Semanas & No \\
\hline Masculino & 27 & $\begin{array}{c}\text { Trauma facial } \\
\text { Trauma Craneoencefalico }\end{array}$ & Ninguno & $\begin{array}{l}\text { Enoftalmos } \\
\text { Distopia } \\
\text { Diplopia } \\
\text { sia III par craneal }\end{array}$ & $\begin{array}{l}14 \text { meses } \\
\text { Injerto escalonado } \\
\text { de calota }\end{array}$ & 16 Semanas & Sí \\
\hline
\end{tabular}

Table 1. Summary of clinical data

\begin{tabular}{|c|c|c|c|c|c|c|}
\hline Gender & $\begin{array}{c}\text { Age } \\
\text { (years) }\end{array}$ & Diagnosis & $\begin{array}{c}\text { Initial } \\
\text { treatment }\end{array}$ & Sequelae & $\begin{array}{c}2^{\text {nd }} \text { Surgical } \\
\text { time }\end{array}$ & Follow-up \\
\hline Female & 17 & Panfacial fracture & $\begin{array}{l}\text { Open reduction, } \\
\text { rigid internal fixation }\end{array}$ & $\begin{array}{c}\text { Enophthalmos } \\
\text { Dystopia } \\
\text { Epiphora }\end{array}$ & $\begin{array}{l}20 \text { months } \\
\text { Tiered skull graft }\end{array}$ & 42 weeks \\
\hline Male & 23 & $\begin{array}{l}\text { Right blow-out } \\
\text { fracture }\end{array}$ & $\begin{array}{l}\text { Open reduction, } \\
\text { rigid internal fixation }\end{array}$ & $\begin{array}{c}\text { Enophthalmos } \\
\text { Dystopia } \\
\text { Diplopia }\end{array}$ & $\begin{array}{l}11 \text { months } \\
\text { Tiered skull graft }\end{array}$ & 16 weeks \\
\hline Male & 27 & $\begin{array}{l}\text { Left blow-out } \\
\text { fracture }\end{array}$ & None & $\begin{array}{c}\text { Enophthalmos } \\
\text { Dystopia } \\
\text { Diplopia }\end{array}$ & $\begin{array}{l}18 \text { months } \\
\text { Tiered skull graft }\end{array}$ & 20 weeks \\
\hline Male & 27 & $\begin{array}{c}\text { Facial trauma } \\
\text { Cranioencephalic } \\
\text { fracture }\end{array}$ & None & $\begin{array}{l}\text { Enophthalmos } \\
\text { Dystopia } \\
\text { Diplopia } \\
\text { ranial nerve paresis }\end{array}$ & $\begin{array}{l}14 \text { months } \\
\text { Tiered skull graft }\end{array}$ & 16 weeks \\
\hline
\end{tabular}

bles. El procedimiento es realizado completamente con hueso autólogo, lo que disminuye los costos.

Se necesita una casuística mayor y seguimiento a más largo plazo para tener resultados estadísticamente significativos.

\section{Bibliografía}

1. Albert D, Jakobiec F. Principles and practice of ophthalmology 1994;5:3441-61.

2. Jeffrey S. An anakysis of 3599 midfacual and 1141 orbital blowout fractures among 4426 united states army soldiers 1980-2001. Otolaryngol Head Neck Surg 2004;130:164-70.

3. Pearl R. Treatment of enophtalmos. Clin Plast Surg 1992;19:342-51.

4. Converse J, Smith B. Enophtalmos and diplopia in fractures of the orbital floor. Br J Plast Surg 1957;9:265-77.

5. Lang W. Traumatic enophtalmos with retention of perfect acuity of vision. Trans Ophtalmol Soc UK 1889;9:41-5.

6. Waterhouse N, Lyne J, Urdang M, Garey L. An investigation into the mechanism of orbital blowout fractures. Br J Plast Surg 1999;52:607-12. chondral bone. These differences are the basis of the differential resorption of the grafts. Ozaki and Buchman, in 1998, reported that cortical grafts are reabsorbed less than cancellous bone grafts and attribute this finding to the bone architecture rather than its embryologic origin.

With respect to donor site morbidity, Krauss and Gatot, ${ }^{12}$ in 2001, evaluate the efficacy of the repair of orbital floor defects with nasoseptal cartilage, encountering a high success rate with minimum donor site morbidity. Castellani, in 2002, repaired defects in the orbital floor with cartilage from the ear, achieving more than $90 \%$ success con minimal morbidity. ${ }^{13}$

Another material used is preformed titanium mesh, which has the advantage of restoring orbital anatomy in almost all its details. In 2006, Schon and Metzger ${ }^{14}$ achieved 100\% success in the repair of orbital floor defects, with additional advantages like ease of placement, shorter surgical time, greater precision, and less invasiveness. With the tiered skull graft, we obtained the same benefits without having to place foreign bodies in direct relation with the eyeball, which entails risk. 
7. Ahmad $F$, y colsl. Strain gauge biomechanical evaluation of forces in orbital floor fractures. Br J Plastic Surg 2003;56:3-9.

8. Lorenz $\mathrm{H}$, Longaker $\mathrm{M}$, Kawamoto $\mathrm{H}$. Primary and secondary orbit surgery: The transconjunctival approach. Plast Reconstr Surg 1999;103:1124-28.

9. Manganello-Souza LC, De Freitas RR. Transconjunctival approach to zygomatic and orbital floor fractures. Int J Oral Maxillofac Surg 1997;26:31-6.

10. Grant MP, Iliff NT, Manson PN. Strategies for the treatment of enophthalmos. Clin Plast Surg 1997;24:539-50.

11. Peterson. Principals of oral and maxillofacial surgery 2004;2:650-75.

12. Graus M, Gatot A. Repair of traumatic inferior orbital wall defects UIT nasoseptal cartilage. J Oral Maxillofac Surg 2001;59:1397-400.

13. Castellani A, Negrini S. Treatment of orbital floor blowout fractures UIT conchal auricular cartilage graft: A report on 14 cases. J Oral Maxillofac Surg 2002; 60:14137.

14. Schon R, Metzger M. Individually preformed titanium mesh implants for a true to original repair of orbital fractures. Int J Oral Maxillofac Surg 2006;12:542-9.

15. Muñoz M. Reconstruction of orbital fractures with dehydrated human dura mater. J Oral Maxillofac Surg 2000;58:1361-6.

16. Nkenke E. Hertel exophtalmometry versus computed tomography and optical $3 \mathrm{D}$ imaging for the determination of the globe position in zygomatic fractures. Int J Oral Maxillofac Surg 2004;33:125-33.

17. Kubato Z, et al. Diagnosis and results of treatment of blowout fracture of the orbital floor. Klin Oczna 1994;96:158-60.

18. Harstein M. Update on orbital floor fractures: Indications and timing for repair. Facial Plastic Surg 2000;16:95-106.

19. Martin K. Individual CAD/CAM fabricated glass-bioceramic implants in reconstructive surgery of the bony orbital floor. Plast Reconstr Surg 2006;117:565-72.

20. Bilge TB. Reconstruction of orbital floor and maxilla with divided vascularised calvarial bone flap in one session. J Plast, Reconst \& Aesthet Surg 2006;59:130511.

21. Jehad AS. Bioresorbable poly-I/dl-lactide plates are reliable for repairing large inferior orbital wall bony defects: A pilot study. J Oral Maxillofac Surg 2006; 64:47-55.

22. Metzger M. Anatomical 3D pre-bent titanium implant for orbital floor fractures. Ophthalmology 2006;113:1863-8.

23. Hinohira Y. Endoscopic endonasal reduction of blowout fractures of the orbital floor. Otolaryngology Head Neck Surg 2005;133:741-7.
Muñoz - Guerra et al., in 2000, enumerate the disadvantages of autogenous and alloplastic materials. With respect to autogenous materials, they mention unpredictable resorption rate, implant mobility, donor site morbidity, and extreme difficulty in recovering the lost orbital anatomy. With regard to alloplastic materials, they note infection, implant extrusion, residual tissue reaction, and diplopia. ${ }^{15}$

\section{Conclusions}

The technique presented here for the reconstruction of the orbital floor is simple, easily executed, and has predictable results. The procedure is performed completely with autologous bone, which reduces costs.

More cases and long-term follow-up are needed to obtain statistically significant results. 